\title{
PROGRAM KEMITRAAN MASYARAKAT (PKM) TEKNIK PEMBELAJARAN KREATIF PADA GURU PAUD DI KELURAHAN TUMINTING KOTA MANADO
}

\author{
Lenie Ratag \\ Universitas Negeri Manado \\ lenieratag23@gmail.com
}

\begin{abstract}
Abstrak
Program Kemitraan Masyarakat ini bertujuan untuk: 1) Peningkatan Kompetensi dan Keterampilan Tenaga Pendidik di PAUD Kelurahan Tuminting Kota Manado, 2) agar ditemukan metode pembelajaran yang dianggap inovatif dan menarik untuk PAUD Kelurahan Tuminting Kota Manado. Program Kemitraan Mayarakat ini bertempat di Kelurahan Tuminting Kota Manado dengan menggunakan metode diskusi dan lokakarya. Simpulan yang dihasilkan adalah: 1). Pelaksanan seluruh program kegiatan kemitraan berjalan dengan lancar karena partisipasi mitra baik pengolala maupun pendidik Paud yang bersedia secara aktif mengikuti pelatihan dan kegiatan pendampingan dalam upaya perbaikan lembaganya, 2). Metode pembelajaran yang kreatif inovatif akan semakin banyak masyarakat yang mempercayakan anak usia dini dididik/ di sekolahkan di PAUD Kelurahan Tuminting Kota Manado, 3). Ketercapaian tujuan program, yakni peningkatan kemampuan dan kompetensi Tenaga Pendidik dalam melakukan pengembangan program pembelajaran anak-usia dini serta Manfaat yang diperoleh peserta dan lembaga juga menunjukan hasil yang positif.
\end{abstract}

Kata kunci: PAUD, Kelurahan Tuminting, Tenaga Pendidik

\section{PENDAHULUAN}

\section{Analisis Situasi}

Pendidikan merupakan aspek yang penting bagi kemajuan sebuah bangsa. Maka untuk menunjang hal tersebut setiap warga Negara harus dan wajib mengikuti jenjang pendidikan, baik jenjang pendidikan anak usia dini, pendidikan dasar, pendidikan menengah maupun tinggi. Dalam bidang pendidikan seorang anak dari lahir memerlukan pelayanan yang tepat dalam pemenuhan kebutuhan pendidikan disertai dengan Pemahaman mengenai karakteristik anak sesuai pertumbuhan dan perkembangannya akan sangat membantu dalam menyesuaikan proses belajar bagi anak dengan usia, kebutuhan, dan kondisi masing-masing, baik secara intelektual, emosional dan social Pendidikan anak usia dini (PAUD) adalah jenjang pendidikan sebelum jenjang pendidikan dasar yang merupakan suatu upaya pembinaan yang ditujukan bagi anak sejak lahir sampai dengan usia enam tahun yang dilakukan melalui pemberian rangsangan pendidikan untuk membantu pertumbuhan dan perkembangan jasmani dan rohani agar anak memiliki kesiapan dalam memasuki pendidikan lebih lanjut, yang diselenggarakan pada jalur formal, nonformal, dan informal [1].

Pendidikan anak usia dini kerap disebut dalam Strategi Pendidikan 2020 Bank Dunia, 
yang memaparkan agenda 10 tahun ke depan di bidang pendidikan, dengan tujuan "Pembelajaraan untuk Semua" [2]. Pendidikan anak usia dini (PAUD) sangat strategis dalam pengembangan sumber daya manusia suatu bangsa. Tak hanya untuk menyiapkan tumbuh kembang anak menjadi sehat dan pintar, tapi juga berkarakter. Lahirnya UU No 6/2014 tentang Desa dan adanya dana besar yang akan masuk desa, posisi desa makin penting, termasuk pengembangan PAUD, untuk semua. Pedoman Umum PAUD Holistik yang terintegrasi yang dikeluarkan Kementerian Perencanaan Pembangunan Nasional/Bappenas 2009, menekankan pengembangan anak usia dini secara holistik-integratif. Institusionalisasi PAUD holistik yang terintegrasi bukan membuat layanan baru, melainkan bagaimana layanan yang sudah ada disinergikan dengan dengan menggerakkan kader pembangunan desa secara optimal, termasuk peningkatan pemahaman orang tua dalam tumbuh kembang anak. Mereka tak hanya mendampingi orang tua yang memiliki balita, tapi juga bisa dilatih meningkatkan kemampuan orang tua dalam pengasuhan dan tumbuh kembang anak. Sinergi aktivitas yang diprakarsai desa/kelurahan ini akan mampu menggerakkan semua potensi yang selama ini tidak optimal karena tidak ada aktivitas yang mampu menjadi jangkar untuk mereka berinteraksi [3].

Salah satu sarana yang dapat dipergunakan untuk mengembangkan kemampuan atau potensi dalam pembelajaran anak TK/RA adalah melalui penggunaan alat peraga/permainan yang mengandung nilai pendidikan. Penggunaan Alat Peraga dapat dilakukan untuk mencapai berbagai tujuan dari pengembangan nilai-nilai agama dan moral dimana proses pembelajaran pada anak TK/RA masih dalam ranah bermain sambil belajar. Ketersediaan tersebut tentunya sangat menunjang proses pembelajaran secara efektif dan menyenangkan sehingga anak didik dapat mengembangkan berbagai potensi yang dimilikinya secara optimal. Sebagaimana hasil penelitian Syarkani dan Siraj menemukan bahwa media pembelajaran terbukti berpengaruh terhadap efektivitas proses belajar dan mengajar. Melalui media pembelajaran, peserta didik ikut terlibat secara aktif dalam menemukan pengetahuan-pengetahuan baru yang bersumber dari lingkungan di sekitar mereka [4].

Untuk meningkatkan kualitas berjalannya layanan pendidikan anak usia dini harus dilakukan suatu upaya peningkatan. Salah satunya yakni dengan meningkatkan kualitas Sumber Daya Manusia yang bergerak langsung pada bidang ini. Dalam standar pendidik dan tenaga kependidikan menyebutkan kualifikasi pendidik satuan pendidikan anak usia dini yakni a. memiliki ijazah Diploma empat (D-IV) atau Sarjana (S1) dalam bidang pendidikan anak usia dini 
yang diperoleh dari program studi terakreditasi, atau b. memiliki ijazah diploma empat (D-IV) atau sarjana (S1) kependidikan lain yang relevan atau psikologi yang diperoleh dari program studi terakreditasi dan memiliki sertifikat Pendidikan Profesi Guru (PPG) PAUD dari perguruan tinggi yang terakreditasi. Selain kualifikasi tersebut pendidik juga diharapkan memiliki Kompetensi Guru PAUD dikembangkan secara utuh mencakup kompetensi pedagogik, kepribadian, sosial, dan professional [5].

Eksistensi PAUD di Kelurahan Tuminting Kota Manado ini diharapkan bisa menjadi tempat bermain sambil belajar yang menyenangkan dan edukatif pada anak usia dini. Masa usia dini atau disebut masa golden age dimana masa ini adalah masa emas pertumbuhan anak yang harus di prioritaskan perkembangannya semenjak lahir hingga usia pertumbuhan 4 tahun, sebagai mana amanat dalam Undangundang SISDIKNAS bahwa salah satu tujuan Pendidikan non formal PAUD adalah mengembangkan potensi kecerdasan spiritual, intelektual, emosional, estetis, kinestetis, dan social peserta didik pada masa emas pertumbuhannya dalam lingkungan bermain yang edukatif dan menyenangkan.

Dibutuhkan pengetahuan yang lebih untuk orang dewasa untuk mengembangkan semua potensi pada anak secara maksimal. Orang dewasa dalam hal ini pendidik dan pengelola Lembaga PAUD membutuhkan kesempatan dan peluang peningkatan potensi dirinya dalam upaya mengembangkan potensi perkembangan anak secara maksimal. Oleh karena itu perlu di berikan pelatihan kaitannya dengan proses pembelajaran anak usia dini. Selain itu juga dapat membantu pengelola dan pendidik PAUD untuk melek informasi yang akan membawa pengaruh pada kreativitas pengembangan sarana pembelajaran untuk anak usia dini dalam pembelajaran di PAUD. Konsekuensinya, lembaga PAUD perlu menyediakan berbagai kegiatan yang dapat mengembangkan berbagai aspek perkembangan seperti: kognitif, bahasa, sosial, emosi, fisik, dan motoric.

Kreatifitas para pendidik pada PAUD dianggap perlu dan penting dikarenakan anak-anak usia 0-6 tahun pada dasarnya masih senang bermain daripada harus belajar duduk di kelas dari pagi sampai siang [6]. Maka dari itu, walaupun pendidik pada PAUD sudah memiliki kualifikasi pendidikan yang cukup dan dapat menguasai bahan ajaran yang ditentukan, tetapi kurang mampu mengemasnya dalam kegiatan belajarmengajar kepada peserta didik, mengakibatkan peserta didik akan cepat bosan dan tentunya bahan ajaran yang disampaikan tidak akan diterima dengan baik oleh perserta didik. Sampai saat ini PAUD pada jalur formal dan non formal belum mempunyai kurikulum tetap yang ditetapkan oleh pemerintah, sehingga 
masing-masing lembaga PAUD harus menyusun sendiri dengan baik metode pembelajaran yang efektif sesuai dengan kondisi dan keberadaannya. Pada taraf PAUD metode yang banyak digunakan adalah metode belajar sambil bermain, karena lewat bermain, anak tidak merasa dipaksa untuk belajar. Dalam pelaksanaan metode pembelajaran belajar sambil bermain PAUD PKK Al Ikhsan tidak berjalan efektif karena sarana pembelajaran yang terbatas dan cara penyampaian materi pembelajaran yang kurang menarik. Kurangnya sarana dan prasana penunjang pendidikan sangat mempengaruhi pelaksanaan proses kegiatan belajar mengajar. Hal tersebut bisa menghambat kreatifitas para pendidik sehingga pembelajaran terasa membosankan. Sarana dan prasarana pembelajaran yang dimiliki masih konvensional ( papan tulis, alat permainan dari kayu dan bahan ajar berupa poster), sedangkan sarana dan prasarana untuk bermain outdoor berupa jungkitan dan ayunan dalam kondisi kurang baik sehingga kurang aman untuk digunakan.

\section{Permasalahan Mitra}

Berdasarkan analisis situasi diatas maka ditemukan permasalahan mitra sebagai berikut:

1. Kompetensi dan keterampilan tenaga pendidik belum memenuhi standar akreditasi Lembaga.
2. Metode pembelajaran di PAUD Kelurahan Tuminting Kota Manado yang dianggap belum inovatif

\section{SOLUSI DAN TARGET LUARAN}

\section{Luaran dan Target Capaian}

Rencana Luaran

1. Peningkatan Kompetensi dan Keterampilan Tenaga Pendidik di PAUD Kelurahan Tuminting Kota Manado

2. Ditemukan metode pembelajaran yang dianggap inovatif dan menarik untuk PAUD Kelurahan Tuminting Kota Manado

Solusi yang ditawarkan untuk mengatasi permasalahan yang dihadapi di PAUD Kelurahan Tuminting Kota Manado adalah:

1. Memberikan pendampingan mengenai peningkatan kompetensi dan keterampilan bagi tenaga pendidik / Guru di PAUD Kelurahan Tuminting Kota Manado.

2. Memberikan Pelatihan pembuatan media pembelajaran dari bahan daur ulang kepada pendidik, wali murid dan pengelola lembaga dalam kegiatan parenting. Wali murid dilibatkan dengan tujuan mereka bisa membuatnya di rumah. Dengan 
pelatihan ini diharapkan pendidik lebih kreatif dan inovatif dalam pelaksanaan belajar mengajar sehingga tidak membosankan. Dengan bahan bekas yang seharusnya dibuang dan jadi sampah bisa diubah/disulap menjadi alat alat edukasi tanpa mengeluarkan banyak biaya

3. Memberikan Pelatihan metode pembelajaran yang kreatif dan inovatif berbasis komputer kepada para pendidik sehingga mereka mengetahui bagaimana cara memperkenalkan komputer pada anak yang membuat anak merasa senang dan nyaman dalam belajar. Program yang bisa digunakan adalah program animasi (software) yang bersifat edutainment yaitu perpaduan antara pendidikan (education) dan hiburan (entertainment). Selain itu edutainment mempunyai kemampuan menumbuh kembangkan kreatifitas dan imajinasi anak serta melatih saraf motorik anak, sehingga anak dapat belajar sambil bermain

\section{METODE PELAKSANAAN}

Metode yang di terapkan dalam melaksanakan program kemitraan masyarakat ini dapat dijelaskan sebagai berikut:

a. Metode diskusi
Melaksanakan Focus Group Discussion (FGD) antara pengelola, pendidik dan instansi terkait dengan tema pembahasan isu-isu kurikulum pendidikan anak usia dini. Menggunakan metode diskusi berarti :

1. Dibagi dalam beberapa kelompok

2. Dapat mempertinggi kegiatan sebagai keseluruhan dan kesatuan

3. Dapat mempertinggi partisipasi secara individual

4. Rasa sosial dapat dikembangkan, karena bisa saling membantu dalam memecahkan masalah, mendorong rasa kesatuan

5. Memberi kemungkinan untuk saling mengemukakan pendapat

6. Merupakan pendekatan yang demokratis

7. Memperluas pandangan 8) Menghayati kepemimpinan bersamasama

8. Membantu mengembangkan kepemimpinan [7].

Metode diskusi dilaksanakan sepanjang proses pendampingan berlangsung. Diskusi berlangsung dari multi arah, yakni antar peserta dengan peserta dan juga antara peserta denga pemberi materi pelatihan. Diharapkan dalam proses ini, permasalahan yang ditemukan dalam pelaksanaan pembelajaran disekolah minggu dapat 
terselesaikan.

b. Metode Lokakarya/Workshop

Lokakarya (Inggris: workshop) adalah suatu acara di mana beberapa orang berkumpul untuk memecahkan masalah tertentu dan mencari solusinya. Sebuah lokakarya adalah pertemuan ilmiah yang kecil. Sekelompok orang yang memiliki perhatian yang sama berkumpul bersama di bawah kepemimpinan beberapa orang ahli untuk menggali satu atau beberapa aspek khusus suatu topik. Sub-sub kelompok dibentuk untuk tujuan mendengarkan ceramahceramah, melihat demonstrasidemonstrasi, mendiskusikan berbagai aspek topik, mempelajari, mengerjakan, mempraktekkan, dan mengevaluasinya. Sebuah workshop biasanya terdiri atas pimpinan workshop, anggota, dan narasumber. Metode lokakarya atau workshop dilakukan untuk memberikan bekal keterampilan pada peserta pendampingan mengenai Peningkatan Kompetensi dan Keterampilan Tenaga Pendidik di PAUD Kelurahan Tuminting Kota Manado, Metode pembelajaran yang dianggap inovatif dan menarik untuk PAUD Kelurahan Tuminting Kota Manado.

\section{HASIL DAN PEMBAHASAN}

Setelah di tahap awal melakukan survei dan menganalisis masalah yang dialami oleh mitra. Kami melakukan diskusi dengan mitra PKM yaitu tentang memberdayakan diri dengan menambah pengetahuan dan pengalaman dalam Peningkatan Kompetensi dan Keterampilan Tenaga Pendidik di PAUD Kelurahan Tuminting Kota Manado serta motivasi untuk memantau tumbuh kembang anak usia dini secara berkala. Selanjutnya lebih jauh lagi kami melakukan Diskusi tentang kurikulum TPA sebagai pedoman dalam pengasuhan dan pendampingan anak usia dini.

Memberikan pelatihan tentang Manajemen Organisasi PAUD, Pengelolaan adalah suatu proses perencanaan, pengorganisaian, kepemimpinan dan pengendalian upaya anggota organisasi dimana keempat proses tersebut mempunyai fungsi masing masing untuk mencapai suatu tujuan organisasi. Dalam pendidikan anak usia dini juga harus adanya pengelolaan yang baik dan sesuai dengan ketentuan-ketentuanya. Suyadi menyatakan bahwa: Pengelolaan Pendidikan anak usia dini mempunyai tujuan meningkatkan dan memaksimalkan segenap daya pendidikan sehingga mampu mencapai tujuan, dan sebagai acuan pelaksanaan penyelenggaraan pendidikan disekolah sekaligus sebagai alat evaluasi penyelenggaraan kegiatan baik selama pengelolaa berlangsung maupun akhir tahun pembelajaran [8].

Memberikan Pelatihan pembuatan media pembelajaran dari bahan daur ulang, Kegiatan ini melibatkan para wali murid dengan tujuan mereka bisa membuatnya di rumah, karena dengan bahan bekas yang 
seharusnya dibuang dan jadi sampah bisa diubah/disulap menjadi alat alat edukasi tanpa mengeluarkan banyak biaya.

Memberikan Pelatihan metode pembelajaran yang kreatif dan inovatif berbasis computer, Media pembelajaran merupakan sub sistem dari sistem pembelajaran, jika tidak disediakan maka akan terdapat kesenjangan dalam mencapai tujuan pembelajaran, seperti terjadinya perbedaan persepsi terhadap materi pembelajaran yang berakibat hasil belajar murid tidak optimal. Media pembelajaran dipilih oleh guru sesuai dengan tujuan pembelajaran dan dapat dimanfaat oleh murid di dalam kelas maupun di luar kelas sesuai dengan kegiatan yang akan dilakukan. Perkembangan media pembelajaran sangat beragam. Media Penyaji yaitu media yang mampu menyediakan informasi, misal gambar, poster, foto (yang digunakan sebagai alat peraga), transparasi, radio, telepon, film, televisi, multimedia (kit). Media objek yaitu media yang informasi sepewrti realita, replika, modul benda tiruan. Media interaktif yaitu media yang memungkinkan untuk berinteraksi selama mengikuti pembelajaran, misal scrabble, puzzle, laboratorium atau komputer.

Kegiatan metode pembelajaran dengan media interaktif ini telah berhasil disusun bersama dengan peserta. Pada pembelajaran ini proses pengembangan kreatifitas telah menstimulasi pengembangan diri dari aspek emosi, sosial ditandai dengan setiap peserta mengambil dan mengolah sendiri permainan yang disediakan. Setiap peserta telah menciptakan sesuatu sesuai dengan keinginannya. Kemudian menyampaikannya pada orang lain. Setelah itu berdiskusi di dalam kelompok untuk menciptakan sesuatu dan setelahnya menunjukkan, menceritakan, menampilkan karyanya tersebut. Pada permainan tersebut semua kelompok pernah menampilkan sesuatu secara spontan dan menikmatinya bersamasama.

Pelaksanaan pelatihan dan pendampingan yang dilakukan secara komprehensif dengan melibatkan tenaga pendidik di PAUD Kelurahan Tuminting Kota Manado telah berhasil meningkatnya pengetahuan, pemahaman, dan keterampilan guru PAUD sehingga mampu membuat alat peraga edukatif berbasis nilai-nilai Islam. Mereka yang sebelumnya kurang kreatif dalam memanfaatkan potensi lokal dan belum mengintegrasikan nilai-nilai Islam dalam merancang media pembelajaran, kini menjadi lebih kreatif dalam mengembangkan alat peraga edukatif kepada siswa di PAUD Kelurahan Tuminting Kota Manado.

\section{KESIMPULAN DAN SARAN}

\section{Kesimpulan}

1. Pelaksanan seluruh program kegiatan kemitraan berjalan dengan lancar karena partisipasi mitra baik pengolala 
maupun pendidik Paud yang bersedia secara aktif mengikuti pelatihan dan kegiatan pendampingan dalam upaya perbaikan lembaganya .

2. Metode pembelajaran yang kreatif inovatif akan semakin banyak masyarakat yang mempercayakan anak usia dini dididik/ di sekolahkan di PAUD Kelurahan Tuminting Kota Manado

3. Ketercapaian tujuan program, yakni peningkatan kemampuan dan kompetensi Tenaga Pendidik dalam melakukan pengembangan program pembelajaran anak-usia dini serta Manfaat yang diperoleh peserta dan lembaga juga menunjukan hasil yang positif.

\section{REFERENSI}

[1] Undang-Undang Nomor 20 Tahun 2003 tentang Sistem Pendidikan Nasional

[2] Roesli, Rofita.2016.Pendidikan Anak Usia Dini di Pedesaan,kunci untuk menghidupkan Potensi Indonesia. World Bank Blog

[3] Muttaqin,Tatang.2016. Desa dan PAUD terpadu. Pendidikan di The Interuniversity Center for Social Science Theory and Methodology (ICS) University of Groningen The Netherlands

[4] Syarkani dan Siraj. Pengembangan Media Pembelajaran Berbasis Budaya pada Mahasiswa FKIP Fisika Universitas Al Muslim(Laporan Penelitian DPRM Dikti, 2018).
[5] Kementerian Pendidikan dan Kebudayaan. 2014. Standar Nasional Pendidikan Anak Usia Dini, Jakarta. Available at: https://luk. staff.ugm.ac.id/atur/bsnp/Permendikbud 137-2014StandarNasionalPAUD.pdf.

[6] Depdiknas. 2006. Pedoman Pembelajaran di TK. Jakarta

[7] Roestiyah ,N.K. 2008. Strategi Belajar Mengajar. Jakarta: PT.Rineka Cipta

[8] Suyadi. 2011. Panduan Penelitian Tindakan Kelas Buku Panduan Wajib bagi Para Pendidik. Yogyakarta: DIVA Press. 